\title{
41H070 on Stowe Creek in the upper San Pedro Creek Basin, Houston County, Texas
}

Timothy K. Perttula

Heritage Research Center, Stephen F. Austin State University

Follow this and additional works at: https://scholarworks.sfasu.edu/ita

Part of the American Material Culture Commons, Archaeological Anthropology Commons, Environmental Studies Commons, Other American Studies Commons, Other Arts and Humanities Commons, Other History of Art, Architecture, and Archaeology Commons, and the United States History Commons

Tell us how this article helped you.

This Article is brought to you for free and open access by the Center for Regional Heritage Research at SFA ScholarWorks. It has been accepted for inclusion in Index of Texas Archaeology: Open Access Gray Literature from the Lone Star State by an authorized editor of SFA ScholarWorks. For more information, please contact cdsscholarworks@sfasu.edu. 


\section{H070 on Stowe Creek in the upper San Pedro Creek Basin, Houston County, Texas}

\section{Creative Commons License}

\section{(c) (1) \&}

This work is licensed under a Creative Commons Attribution-NonCommercial 4.0 International License 


\title{
41 HO70 on Stowe Creek in the upper San Pedro Creek Basin, Houston County, Texas
}

\author{
Timothy K. Perttula
}

\section{INTRODUCTION}

Site $41 \mathrm{HO} 70$ in the East Texas Pineywoods (Figure 1) is an ancestral Caddo settlement that was extensively looted by a well-known East Texas looter in 1985. The available information about the site discussed in this article is gleaned from the records and a 1986 artifact collection held by the Texas Archeological Research Laboratory at The University of Texas at Austin (TARL).

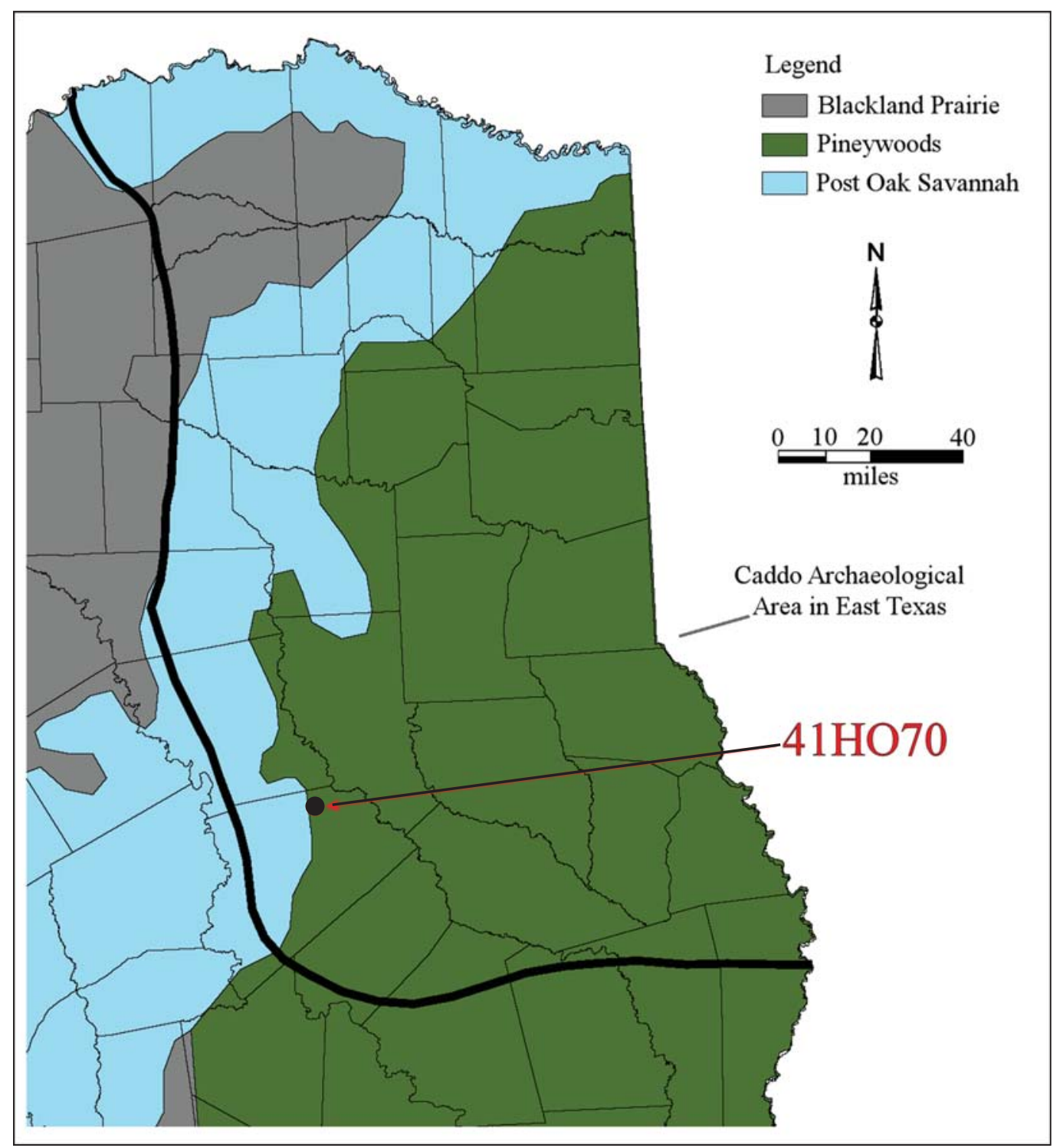

Figure 1. Location of $41 \mathrm{HO} 70$ in the East Texas Pineywoods. 


\section{SITE SETTING}

The site was on a sandy knoll along Stowe Creek, a northward-flowing tributary to San Pedro Creek in the upper reaches of the San Pedro Creek basin. San Pedro Creek is an eastward-flowing tributary to the Neches River, and the confluence of the two streams is not far upstream from the George C. Davis (41CE19) mound center and large village.

The knoll at $41 \mathrm{HO} 70$ was estimated to be $75 \times 75 \mathrm{~m}$ in size (ca. 1.4 acres) and was reputed to have archaeological deposits at least $1.5 \mathrm{~m}$ in depth. Other collectors working the site in 1986 encountered a single burial feature there; this burial was described as an individual in a "sitting position." The upper $75 \mathrm{~cm}$ of the deposit had a well-preserved midden with associated and abundant faunal remains and ancestral Caddo material culture remains. Erwin Roemer obtained a small collection of ceramic sherds from back dirt piles at $41 \mathrm{HO} 70$ in 1986 , and donated it to TARL.

\section{ARTIFACT COLLECTION AT TARL}

Two body sherds from $41 \mathrm{HO} 70$ are from a plain sandy ware, i.e., Goose Creek Plain, var. unspecified. This ceramic ware is associated with Woodland period cultures in the southern part of East Texas, and is evidence that the site was first occupied sometime during the Woodland period, between ca. 500 B.C. and A.D. 800 (see Ellis 2013; Perttula 2013).

The remainder of the ceramic sherds in the TARL collection from $41 \mathrm{HO} 70$ are from an ancestral Caddo occupation. They include:

- 5 plain grog-tempered body sherds

- 1 plain bone-tempered body sherd

- 1 grog-tempered appliqued body sherd

- 2 grog-tempered brushed body sherds

- 1 bone-tempered brushed body sherd

- 1 grog-tempered brushed-appliqued body sherd

- 1 grog-tempered brushed-punctated rim sherd

- 1 grog-tempered grooved body sherd

- 5 grog-tempered incised rim and body sherds

- 1 bone-tempered incised body sherd

- 1 bone-tempered incised-punctated rim sherd

- 2 grog-tempered incised-punctated body sherds

- 1 bone-tempered fingernail punctated rim sherd

- 2 grog-tempered fingernail punctated rim and body sherds

- 1 bone-tempered engraved rim sherd

- 1 grog-tempered engraved bottle sherd

These 27 rim and body sherds (from a minimum of 18 vessels) are from both grog ( $\mathrm{n}=21,78$ percent)and bone-tempered ( $\mathrm{n}=6,22$ percent) vessels. Twenty-one of the sherds are from decorated vessels, including sherds from both utility ware $(n=19)$ and fine ware $(n=2)$.

The incised sherds represent 32 percent of the sherds from utility wares at 41HO70. These are likely all from Dunkin Incised cylindrical jars with diagonal and diagonal opposed decorative elements (Figure 2a-e; see also Suhm and Jelks 1962:37 and Plate 19).

The one incised-punctated rim sherd from $41 \mathrm{HO} 70$ has horizontal and diagonal incised lines on the rim, with a row of linear tool punctations at the rim-body juncture (Figure 3c). One incised-punctated body 


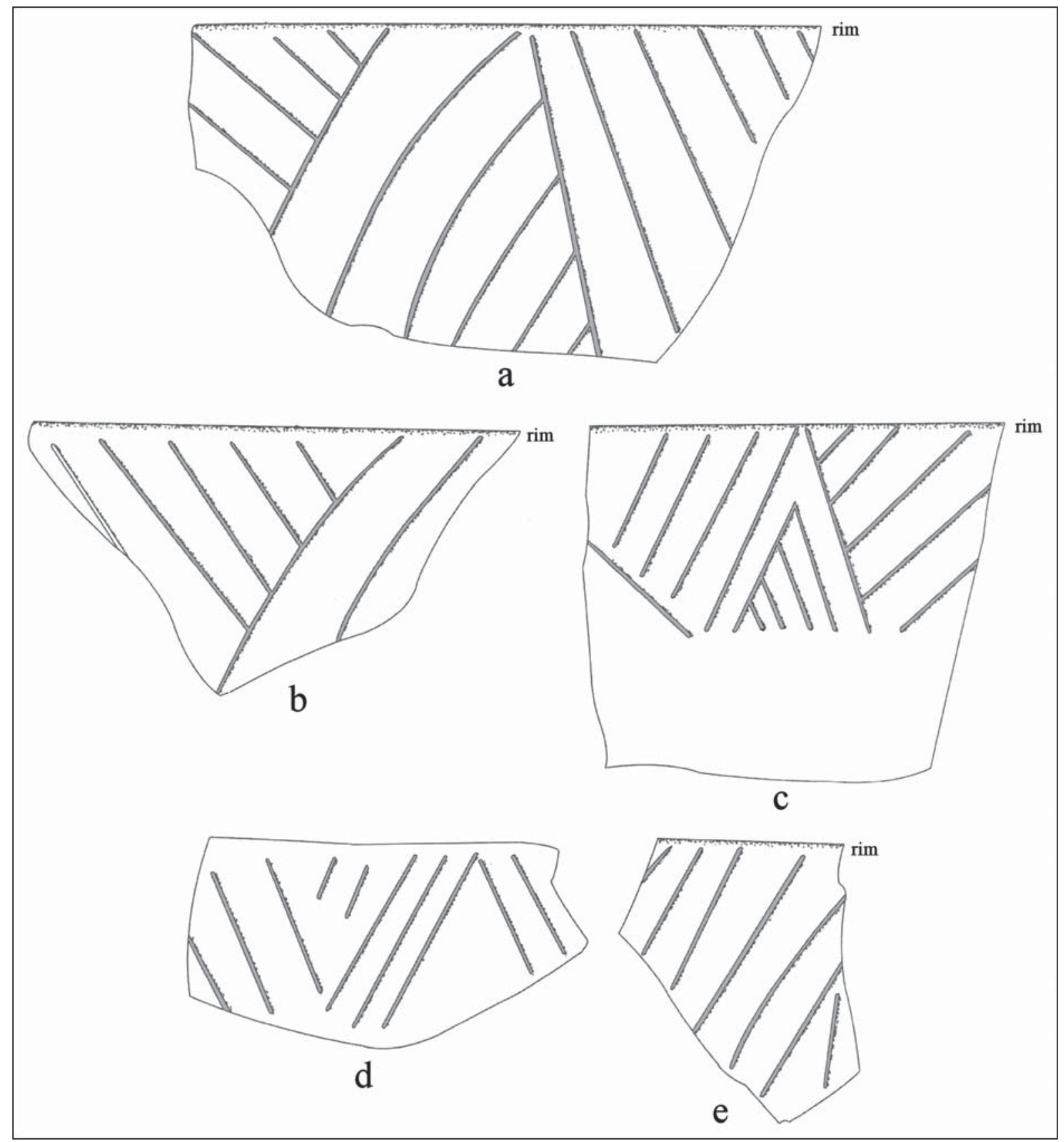

Figure 2. Decorative elements on incised rim sherds from 41HO70.

sherd from another Dunkin Incised vessel has cross-hatched incised lines on the rim and rows of fingernail punctations on the vessel body (Figure 3a). The last incised-punctated body sherd has part of an incised triangle element that is filled with triangular-shaped tool punctations (Figure 3b).

Five of the utility ware sherds (26 percent) have brushed, brushed-appliqued, and brushed-punctated decorative elements. Three body sherds from jars have parallel brushing marks. A rim has horizontal brushing marks as well as a row of fingernail punctations below the vessel lip (Figure 4a). This rim also has a drilled hole, suggesting this rim is from a vessel that was suspended for some purpose. The one brushed-appliqued body sherd has a straight appliqued fillet with parallel brushing marks on either side of the fillet (Figure 4b). The appliqued fillet probably divided the body of a utility ware jar, likely a Pease Brushed-Incised vessel 


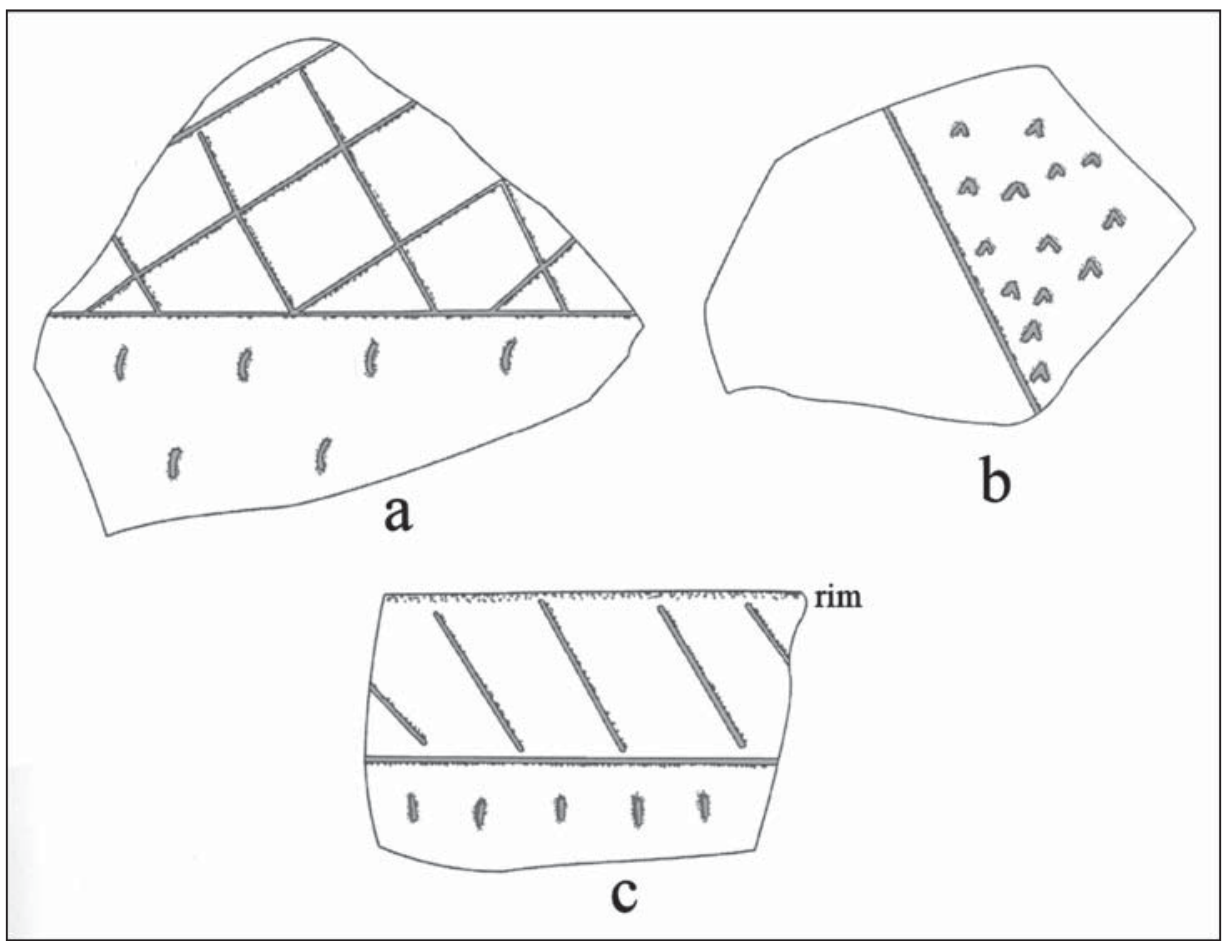

Figure 3. Decorative elements on incised-punctated rim and body sherds from 41HO70: a-b, body sherds; c, rim sherd.

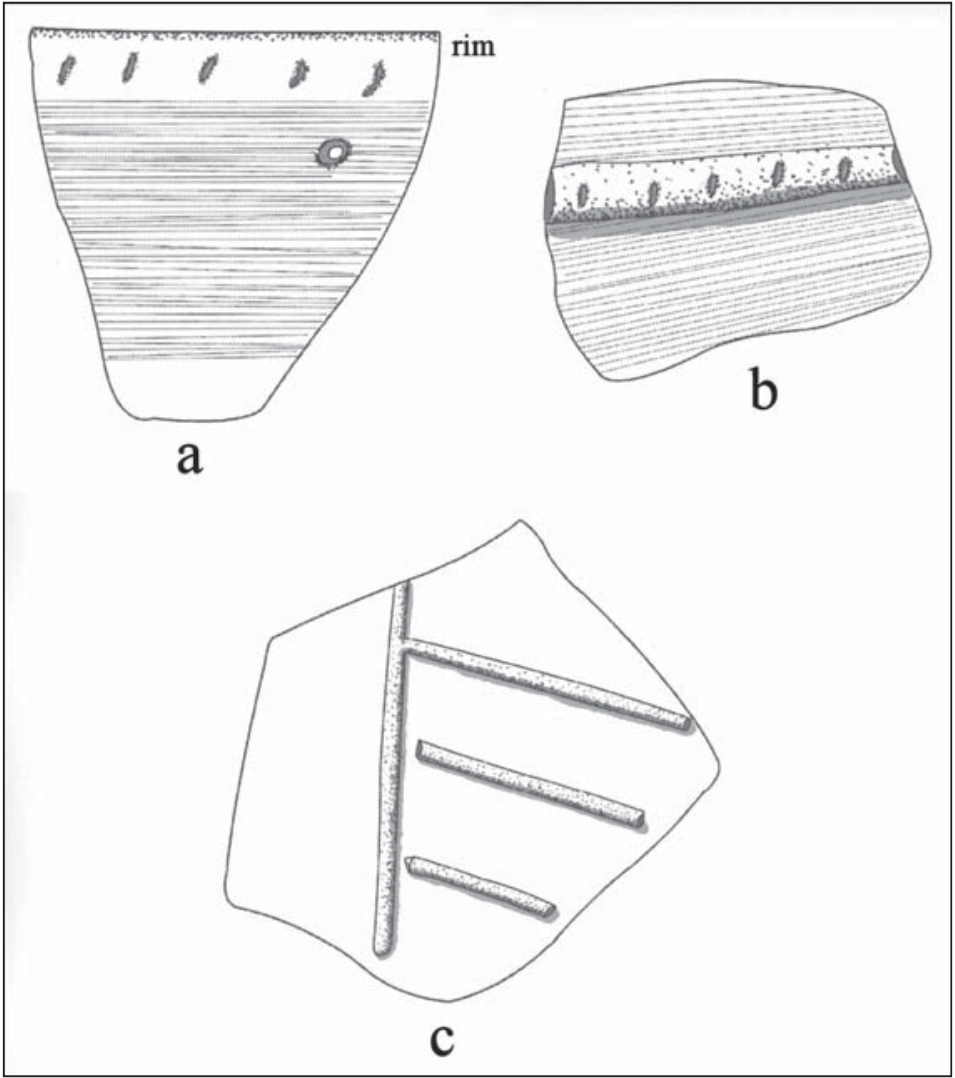

Figure 4. Decorative elements on other utility ware sherds from 41HO70: a, brushed-punctated rim sherd; b, brushed-appliqued body sherd; c, appliqued body sherd. 
(Suhm and Jelks 1962:119 and Plate 60), into panels filled with brushing marks. One grog-tempered body sherd is decorated with opposed appliqued ridges (Figure 4c).

Among the $41 \mathrm{HO} 70$ utility ware sherds are three fingernail punctated rim or body sherds. Two of the sherds have rows of fingernail punctations, while one rim is decorated with randomly placed fingernail punctations.

The one grooved sherd in the sherd collection may reflect a post-A.D. 1680 use of 41HO70. Utility ware jar sherds with grooved decorative elements (i.e., from Lindsey Grooved vessels, see Marceaux 2011) are distributed in two clusters of Caddo sites in the upper Neches and Angelina river basins (Perttula 2015:Figure 8). These sites all date after ca. A.D. 1680 to ca. A.D. 1750 and are historic Caddo sites associated with the Allen phase. However, there are also a few grooved sherds from ca. A.D. 900-1300 contexts at three sites in the Neches, Red, and Sabine River basins, most notably at the George C. Davis site (41CE19; see Newell and Krieger 1949). These grooved sherds are not related either stylistically or temporally with Lindsey Grooved wares, and are likely from Crenshaw Fluted vessels with deep vertical grooves or flutes.

A scalloped rim Holly Fine Engraved sherd from a carinated bowl (see Suhm and Jelks 1962:77) is in the $41 \mathrm{HO} 70$ collection (Figure 5). The other engraved sherd in the collection is a bottle neck sherd with a horizontal line on it, probably from a Hickory Engraved bottle (Suhm and Jelks 1962:71).

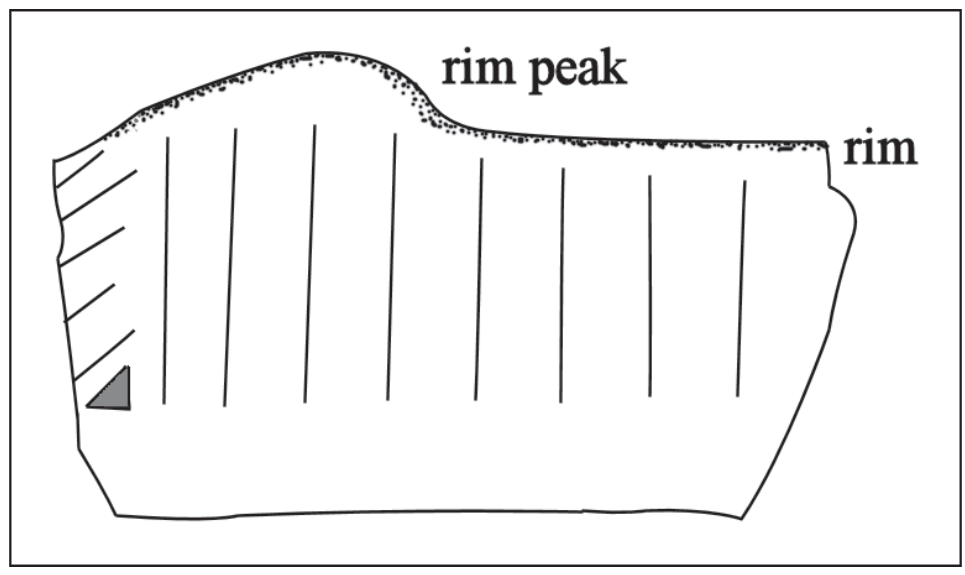

Figure 5. Holly Fine Engraved rim sherd from 41H070.

Ground stone celt fragments were noted to have been recovered at the site during the looting. In addition to the ceramic sherds, the TARL collection from $41 \mathrm{HO} 70$ has 23 burned and unburned large mammal bones. These represent apparently just a small sample of a well-preserved faunal assemblage in the site's midden deposits, including bones from deer, beaver, bison (two specimens), and canid. The canid remains were in a burial, along with an Alba arrow point.

\section{SUMMARY AND CONCLUSIONS}

Site $41 \mathrm{HO} 70$ was looted in 1985, destroying its well preserved ancestral Caddo midden deposits. From the available but limited information about the site, this midden deposit was thick $(0-75 \mathrm{~cm} \mathrm{bs})$, and had abundant faunal remains (and a dog burial) and Caddo artifacts, as well as at least one Caddo burial. Artifacts apparently were still present in the sandy sediments below the midden, to a depth of at least $150 \mathrm{~cm} \mathrm{bs}$, but these deposits may relate to an initial occupation of the site during the Woodland period, based on the presence of Goose Creek Plain, var. unspecified sherds in the small ceramic sherd collection. 
Sherds from at least 18 different grog- and bone-tempered Caddo ceramic vessels were gathered in 1986 from looter back dirt piles and donated to TARL. They include incised, brushed, brushed-appliqued, brushed-punctated, fingernail punctated, grooved, and appliqued sherds from utility ware vessels, including Dunkin Incised and Pease Brushed-Incised, as well as sherds from Holly Fine Engraved and Hickory Engraved carinated bowls and bottles. If these sherds are from a single component, it suggests that $41 \mathrm{HO} 70$ was occupied by Caddo peoples between ca. A.D. 1200-1300, at the latter end of the Caddo settlement at the George C. Davis site (4CE19), the principal mound center in the Neches River basin (Newell and Krieger 1949; Story 1997, 1998, 2000).

\section{ACKNOWLEDGMENTS}

Lance Trask prepared the figures in this article. Jonathan Jarvis at TARL facilitated access to the records and collections from $41 \mathrm{HO} 70$.

\section{REFERENCES CITED}

Ellis, L. W.

2013 Woodland Ceramics in East Texas and a Case Study of Mill Creek Culture Ceramics. Bulletin of the Texas Archeological Society 84:137-180.

Marceaux, P. S.

2011 The Archaeology and Ethnohistory of the Hasinai Caddo: Material Culture and the Course of European Contact. Ph.D. dissertation, Department of Anthropology, The University of Texas at Austin.

Newell, H. P and A. D. Krieger

1949 The George C. Davis Site, Cherokee County, Texas. Memoir No. 5. Society for American Archaeology, Menasha, Wisconsin.

Perttula, T. K.

2013 Caddo Ceramics in East Texas. Bulletin of the Texas Archeological Society 84:181-212.

2015 East Texas Caddo Ceramic Sherd Database. Journal of Northeast Texas Archaeology 51:1-46.

Suhm, D. A. and E. B. Jelks (editors)

1962 Handbook of Texas Archeology: Type Descriptions. Special Publication No. 1, Texas Archeological Society, and Bulletin No. 4, Texas Memorial Museum, Austin. Reprinted in 2009, Gustav's Library, Davenport, Iowa.

Story, D. A.

1997 1968-1970 Archeological Investigations at the George C. Davis Site, Cherokee County, Texas. Bulletin of the Texas Archeological Society 68:1-113.

1998 The George C. Davis Site: Glimpses into Early Caddoan Symbolism and Ideology. In The Native History of the Caddo: Their Place in Southeastern Archeology and Ethnohistory, edited by T. K. Perttula and J. E. Bruseth, pp. 9-43. Studies in Archeology 30. Texas Archeological Research Laboratory The University of Texas at Austin.

2000 Introduction. In The George C. Davis Site, Cherokee County, Texas, by H. P. Newell and A. D. Krieger, pp. 1-31.2nd Edition. Society for American Archaeology, Washington, D.C. 